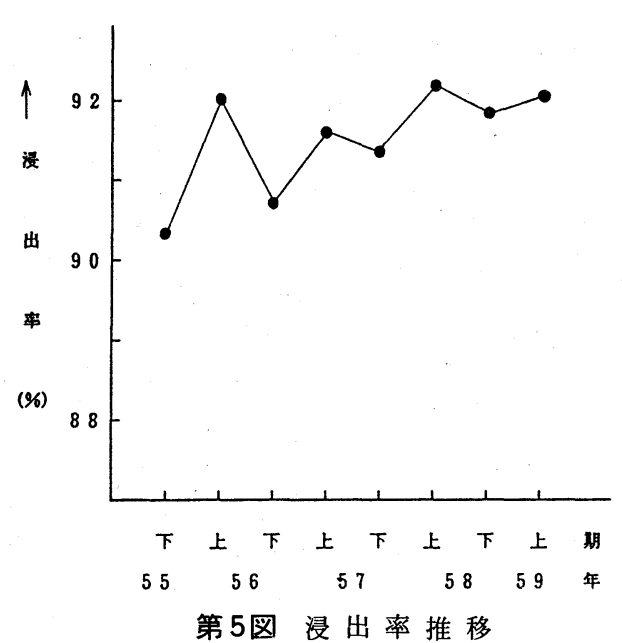

あつた。ところが $4 \cdot 1$ の改善により, 浸出工程での中和・脱鉄管 理は著しく軽減されたことにより, 液量を変動させてもなんら問 題はなくなつた。

そこで操業度に応じた焼鉱量を設定し, 要鉛尾液量は浸出槽入 口の $\mathrm{pH}$ と連動させて調整することにより焼鉱と亜鉛尾液の混合 が自動化された。この結果第 6 四に示すように浸出槽送液の $\mathrm{p} \mathrm{H}$ を安定させることができた。またオンラインのコンピュータで操業 データを種々加工することにより,この操業の安定に役立てている。

\section{5. 改善による効果}

浸出工場において操業の合理化に対して上記の改善を実施した

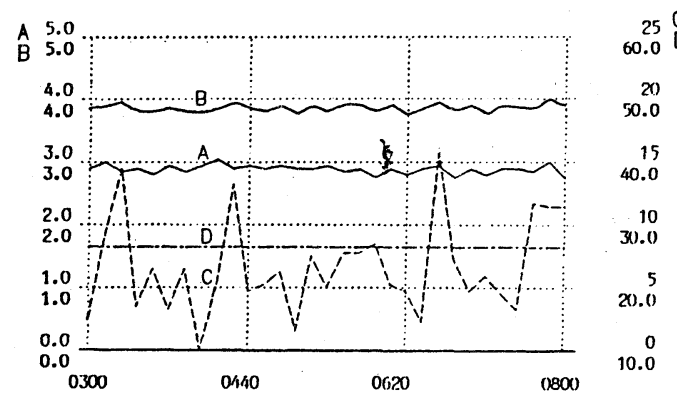

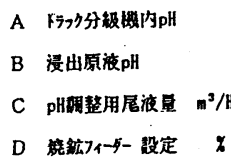

第6図浸出原液 $\mathrm{pH}$ の変動（昭 60.2.8 AM 3：00〜 AM 8：00）

ことにより, 以下の効果が得られた。

(1) 1 人 $\times 3$ シフトの省力化がなされた。

（2）空気吹込用コンプレッサー $(125 \mathrm{~kW}+75 \mathrm{~kW})$ の停止，中 和用焼鉱空気輸送設備の停止等で, $120 \mathrm{MWh} /$ 月の電力を消減した。

(3) 従来 $3 \mathrm{t}$ /月使用していた $\mathrm{KMnO}_{4}$ の添加を廃止した。

(4) $\mathrm{Zn}, \mathrm{Cu}, \mathrm{Cd}$ の浸出率の向上と安定に寄与した。

\section{6. むす び}

以上, 浸出工程で実施した最近の主な改善について脱鉄関係を 中心に述べたが, 今後は複式浸出, 系内液 Mn 濃度の管理等さら にきめこまやかな操業管理により，工程の改善を進めていきたい と考えている。

最後に, これらの改善に対し種々の御指導を賜つた上司ならび に関係各位，さらに実施にあたり率先協力してくれた職場一同に 深く感謝の意を表する。

（3）三池における鉱滓処理について

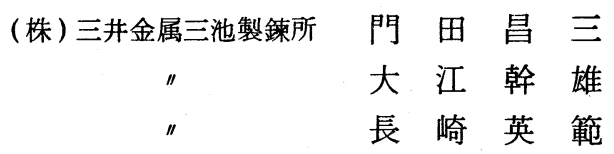

\section{1. 緒言}

三池における鉱涬処理は当所の製鍊方式の変遷とともに歩み続 け，幾多の変革を経ながら今日に至つている。

特に当所の製鍊方式は, 昭和 57 年の焼鉱硫酸工場の休止により, 永年にわたる精鉱中心の製鍊方式から，リサイクル原料を中心と した製鍊方式へと，大変貌を遂げた。

このため原料構成の変化などにより, 今までには見られなかつ た数多くの問題が一度に発生した。

これらの問題に対して試行錯誤を繰返しながら, 諸改善に取り くみ, 現在は，順調に操業を続けている。

今回は, この間における諸改善の内容や操業の現状などについ て紹介する。

\section{2. 鉱漳処理の概要}

\section{$2 \cdot 1$ 鉱滓処理の変遷}

当所の釷涬処理は昭和 27 年の水平蒸留の釷涬処理を目的とした 焼結一熔鉱炬 - 揮発炬方式に始まり, 昭和 40 年の立型蒸留の鉱涬 処理をめざした M F 方式を経て, 現在では立型蒸留の減炉に伴つ てリサイクル原料を処理するMF方式へと受け継がれてきている。
釷涬処理の変遷を当所の製鍊方式と合せて第 1 表に示す。 現在, MF 2 炬, RK炬 3 炬, および立型蒸留炬 12 炉が稼動し ている。

\section{$2 \cdot 2$ 工程の概要}

工程のフローシートを第 1 㘡に示す。

MF の主原料は立型鉱涬, 電鍊涬 ( 赤渣) および製鋼煙灰であ

$\eta ，$ 近年，製鋼煙灰が増加傾向にある。

MF 原料組成と供用比率を第 2 表に示す。

工程は原料に石炭およびバインダであるパルプ廃液を添加し， 乾燥・粉砕後, 製団鉱としてMF炬へ供用する。

MF 炉では，亜鉛および鉛は煙灰（MF粗酸化亜鉛， Zn 50\%，

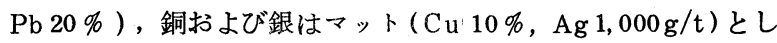
て回収される。

MF炉の概念図を第 2 図に示す。

MF 粗酸化亜鉛は亜鉛涬と混合，造粒した後，焼成および不純 物除去を行なつて R K 鉱とし，立型蒸留炉へ供用する。

$\mathrm{RK}$ 炬の供用原料および $\mathrm{R} \mathrm{K}$ 鉱の組成を第 3 表に示す。

$\mathrm{RK}$ 炉から発生する $\mathrm{RK}$ 煙灰は, 湿式処理により, 塩基性炭酸 带鉛および鉛㳯に仕上げられる。 
第 1 表 鉱涬処理の変遷

\begin{tabular}{|c|c|c|}
\hline 次 & 慗 䗲 方 式 & 莉 - 涬 処 \\
\hline 大正 2 & 水平蒸留炬採業閉始 & \\
\hline 6 & 㟋鉱硫酸工埸探業開始 & \\
\hline 昭和 11 & 业鉛電解工場操業開始 & \\
\hline 27 & & 粪結·塎鉱妒 - 揮発妒方式開始 \\
\hline 29 & 堅型蒸留妒操業開始 & \\
\hline 40 & & MF 1 号知 ( $80 \mathrm{t} / \mathrm{日})$ 探業開始 \\
\hline 41 & 水平蒸留炉休止 & MF 2 号炉 ( $80 t / \theta)$ 操業開始 \\
\hline 44 & & MF 3 号妒 (120t/日) 探業開始 \\
\hline 45 & $\begin{array}{l}\text { 堅型蒸留妒 } 8 \text { 期姑 }(32 \text { 妒) 完成 } \\
\text { (鉛 } 102.000 \mathrm{t} / \text { 年 })\end{array}$ & \\
\hline 48 & $\begin{array}{l}\text { 竪型蒸留妒大型化 } \\
\text { (兴鉛. } 108.000 \mathrm{t} \text { /年) }\end{array}$ & MF 4 号妒（150t/日）探業開始 \\
\hline 49 & & MF 1， 2 号炉統合大型化 (200t/日) \\
\hline 50 & 重鉛電解工場休止 & 新MF I 号妒 (200t/日) 操業開始 \\
\hline 51 & & 㨪結·塎鉱炉 · 揮発妒方式休止 \\
\hline 54 & & MF 1， 2 号統合大型妒休止 \\
\hline 57 & 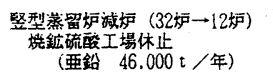 & MF 3 号休止 \\
\hline
\end{tabular}

\section{3. 最近の工程改善}

\section{$3 \cdot 1$ 製鋼煙灰の事前脱塩素}

$\mathrm{MF}$ 炬における製鋼煙灰の供用比率が増加するにつれて, 工程 産出物の塩素品位が高くなり, MF ボイラチューブの腐蝕や, 立 型蒸留炉のレトルト・トラブルなどが発生した。

このため，製鋼煙灰の事前脱塩素を行ない，MF 炬へ供用する

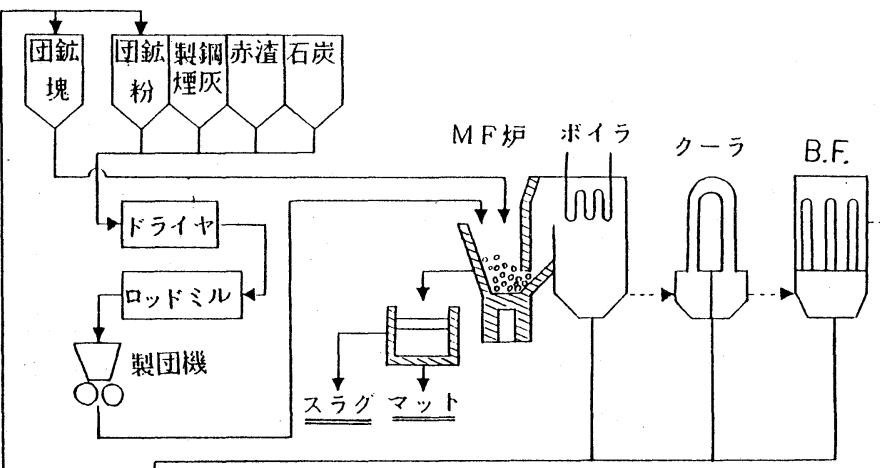

\section{重鉛 $\mathrm{MF}$}

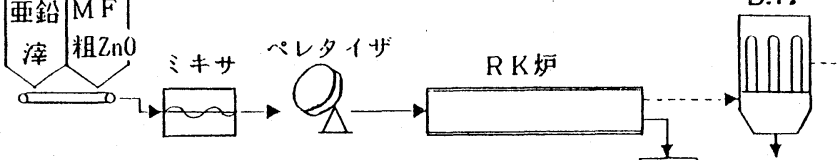

B.F.

脱硫塔

脱硫塔 $140 \mathrm{~m}$ 煙乫
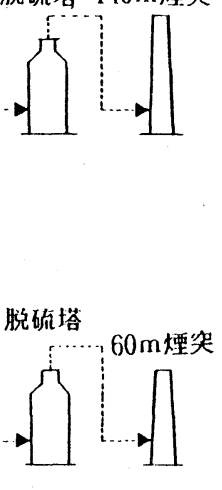

镛

竪型蒸留炉

$\underline{V Z-M M C}$

睘式工程

鉛洋壏基性炭酸重鉛

第1図 三池鉣涬処理系統図

第2 表 MF 原料組成と供用比率

\begin{tabular}{|c|c|c|c|c|c|c|c|c|c|}
\hline & \multicolumn{2}{|c|}{ 組 } & \multicolumn{3}{|c|}{$(\%, g / t)$} & \multicolumn{3}{|c|}{ 件 用 比 策 } \\
\hline & & $\mathrm{Zn}$ & $\mathrm{P}$ b & $\mathrm{Ag}$ & $\mathrm{Cu}$ & c & 52 年 & 55年 & 56 年以降 \\
\hline 製 & 铜煌 灭 & 20 & 4 & 80 & 0.3 & 0 & 5 & 23 & 26 \\
\hline 赤 & 渣 & 18 & 4 & 200 & 0.8 & 0 & 37 & 37 & 18 \\
\hline 堅 & 型鉱 详 & 4 & 5 & 100 & 1 & 20 & 40 & 21 & 21 \\
\hline द & の 他 & & & & & & 18 & 19 & 35 \\
\hline
\end{tabular}

……60 煙乫

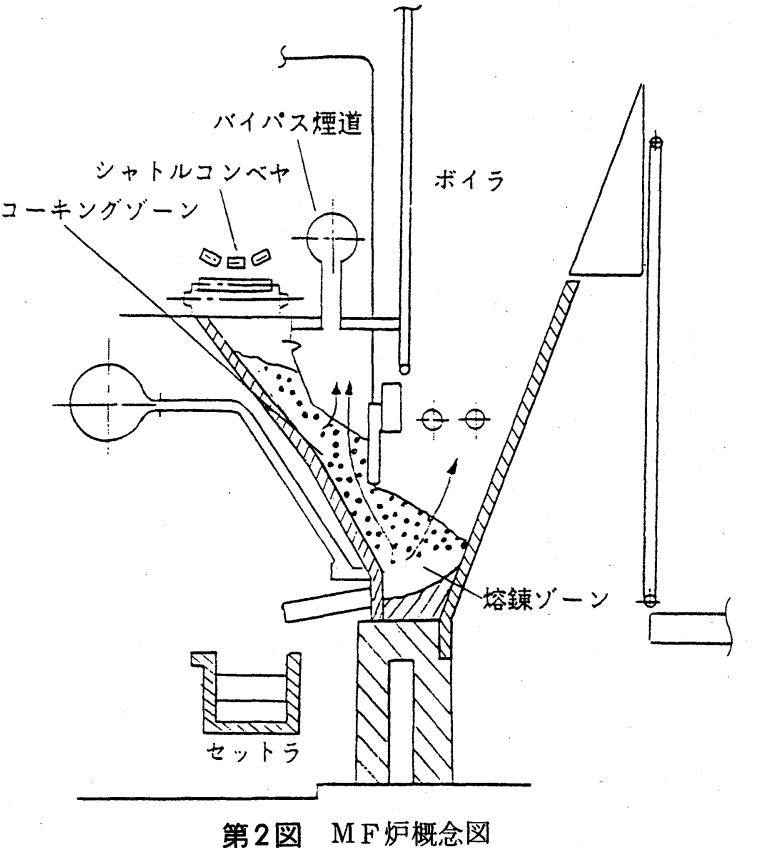

第3 表 $\mathrm{RK}$ 鉱および供用鉱組成

\begin{tabular}{|c|c|c|c|c|c|c|c|c|}
\hline & \multicolumn{2}{|c|}{ 組 } & \multicolumn{2}{|c|}{ 成 $(\%)$} & \multirow{2}{*}{$\begin{array}{c}\text { 滈比重 } \\
(\mathrm{g} / \mathrm{cc})\end{array}$} \\
\hline & & & & $2 n$ & $\mathrm{~Pb}$ & $\mathrm{Cd}$ & C I & \\
\hline 供 & 用 & 造 精 & & 50 & 10 & 0.4 & 3 & 1.3 \\
\hline 柆 & 出 & $\mathrm{R} \mathrm{K}$ & 絋 & 63 & 2 & 0.01 & 0.3 & 2.5 \\
\hline 涯 & 出 & 煙 & 板 & 20 & 30 & 1.5 & 10 & - \\
\hline
\end{tabular}

方法を採用した。

製鋼煙灰は, ペレット状で入荷し，水に 浸漬させても破壊することがなく，ビン中 で通水性が良いことに着目し, 散水式脱塩 素法を採用した。

製鋼煙灰の脱塩素の概念図を第 3 図に示す。

散水は, 工程のアルカリ水を利用し, 一 昼夜サイクルで脱塩素を行なつている。

脱塩素時間と脱塩素率の関係および脱塩 素成績を第 4 困，および第 4 表に示す。

$3 \cdot 2 \mathrm{MF}$ ボイラの改善

MF における塩素負荷が増加するにつれ て,ボイラチューブの腐蝕が激しく, 特に 高温にさらされるスーパーヒータ ( SH) 部

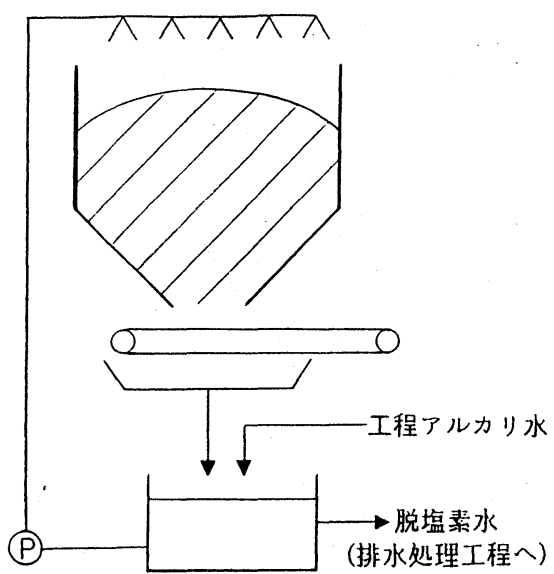

第3図 製鋼煙灰脱塩素概念図 


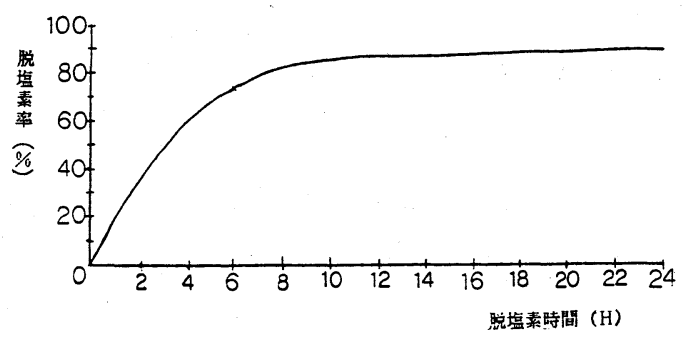

第4 図 脱塩素時間と脱塩素率の関係 第4 表 脱塩素前後の組成

\begin{tabular}{|c|c|c|c|}
\hline & C 1 & $2 n$ & 水䌶 \\
\hline & $\%$ & $\%$ & $\%$ \\
\hline 殿埴萎前 & 4.5 & 20 & $<1$ \\
\hline 赖埴素後 & $<1$ & 20 & 15 \\
\hline
\end{tabular}

(a) 対策前域肉状況.
(原作 $5 \mathrm{~m} / \mathrm{m}$ )

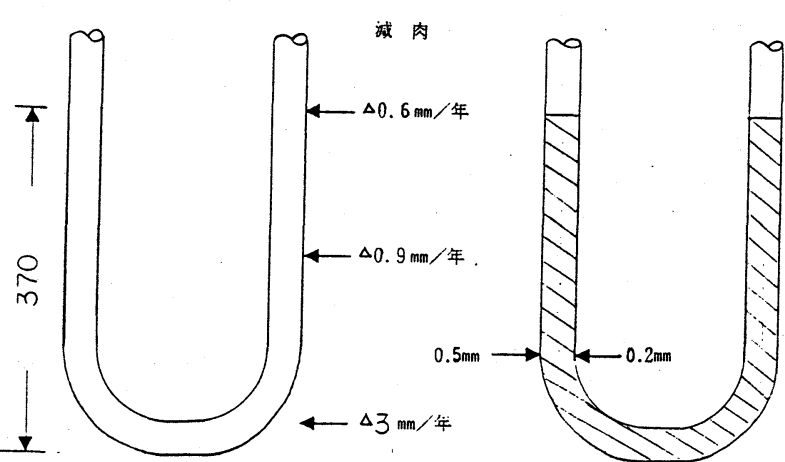

第6図 ボイラーチューブ減肉状況とメタリック熔射施工
第5 表 MF ボイラ仕様

\begin{tabular}{|c|c|c|c|c|c|c|}
\hline & 蒰 発 & 暴氞温度 & S H. 伝篤面稍 & 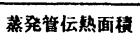 \\
\hline & & & $t / 11$ & c & $\mathrm{m}$ & $m^{m}$ \\
\hline \multirow{2}{*}{1 묵 $\mathrm{MF}$} & 改 & 造 前 & 14.6 & 420 & 401 & 1. 660 \\
\hline & 灌 & 造糸 & 16.3 & 310 & 310 & 1. 751 \\
\hline & & & & & & \\
\hline \multirow{2}{*}{4 묵 $\mathrm{MF}$} & 改 & 造自 & 10.8 & 430 & 308 & 1. 186 \\
\hline & 收 & 造 & 12.2 & 310 & 223 & 1.276 \\
\hline
\end{tabular}

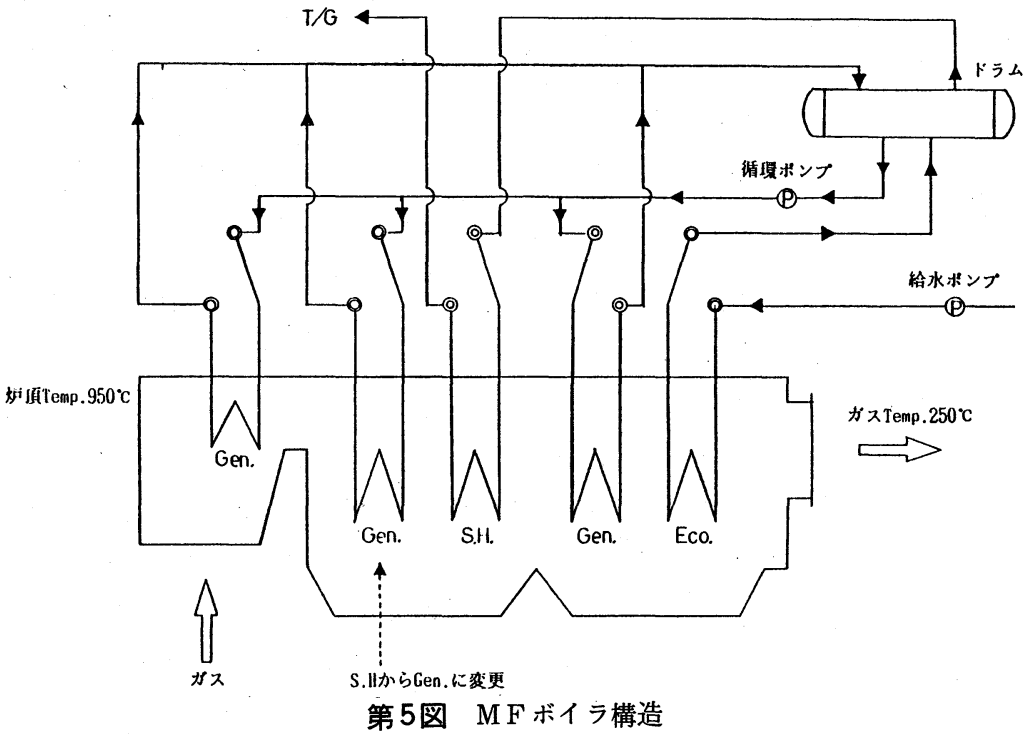

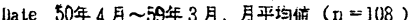

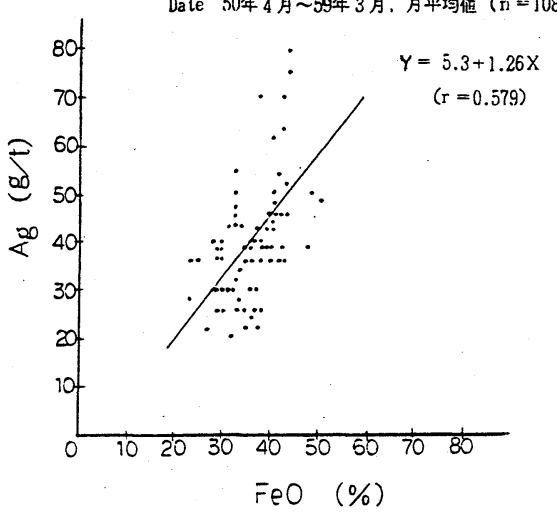

第7図 $\mathrm{MF}$ スラグ中の $\mathrm{FeO}-\mathrm{Ag}$ 相関図

第 6 図に示す。

$3 \cdot 3 \quad \mathrm{MF}$ 組成の適性化

製鋼煙灰による鉄源の増加に伴つて, MF 鍰 の $\mathrm{FeO} / \mathrm{SiO}_{2}$ 比が高くなり, 鍰の融点および比 重の上昇の結果，七ットラでの鍰とマットの分離効率が悪くなつた。 また, 鍰中の $\mathrm{Cu}, \mathrm{Ag}$ と $\mathrm{FeO}$ との間には, 第 7 図に示すように 相関があり, $\mathrm{FeO}$ 品位上昇に伴い, 鍰への $\mathrm{Cu}, \mathrm{Ag}$ 口スが増加す ることがわかつた。

このため, 製団鉱のバインダであるパルフ廃夜の半分量を, 粘 土系のベントナイトに切替え, 鍰中の $\mathrm{FeO} / \mathrm{SiO}_{2}$ 比を低下させ $\mathrm{Cu}, \mathrm{Ag}$ 口スを少なくしている。

MFにおける原料比率と鍰組成の関係を第 6 表に示す。

第6表 原料の変化とスラグ組成 であつたが，最悪時は12か月位に縮まつた。 このため改造の第 1 は, $\mathrm{SH}$ の前半分を蒸 発管に変えることにより, 蒸発量の増加と $\mathrm{SH}$ 部の伝熱面積の減少をはかり, 蒸気温度を下 げ， S H 部の熱負荷を減少させた。

ボイラの構造および改造前後のボイラ仕様 を第 5 四および第 5 表に示す。

改造の第 2 は SH 部の損傷個所がチニーブ の下部のベンド部に集中するため, この部分 に, ニッケル・クロム合金の溶射コーティン グを行なつた。

実機によるコーティング効果は顕著であり， その寿命は，50か月以上と推定している。

チューブの隇肉状況とコーティング状況を

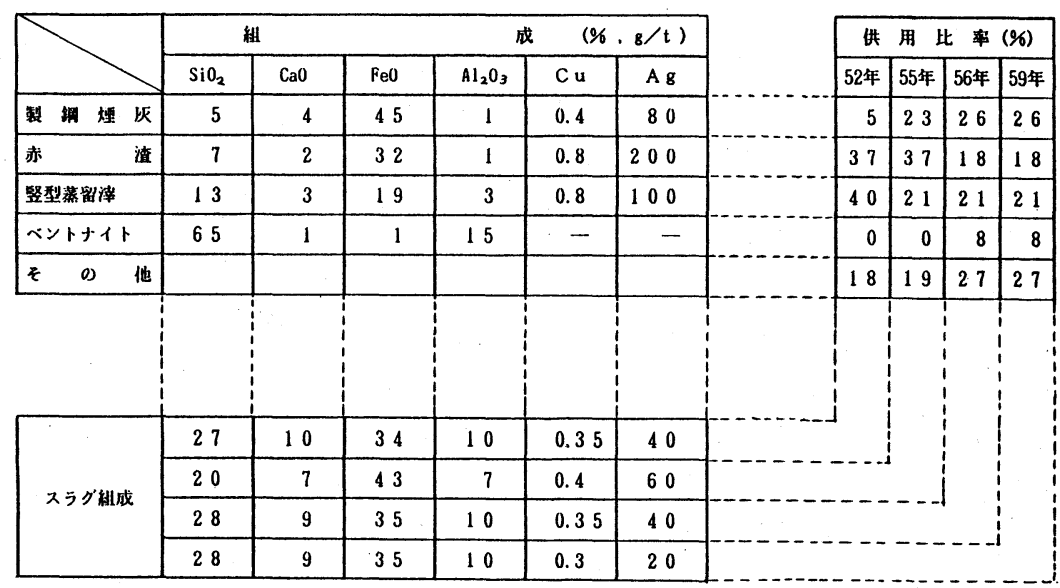


3・4 MF マットの高品位化

従来, $\mathrm{MF}$ マットは, $\mathrm{Cu} 3 \sim 4 \%, \mathrm{Ag} 500 \sim 600 \mathrm{~g} / \mathrm{t}$ の低品位
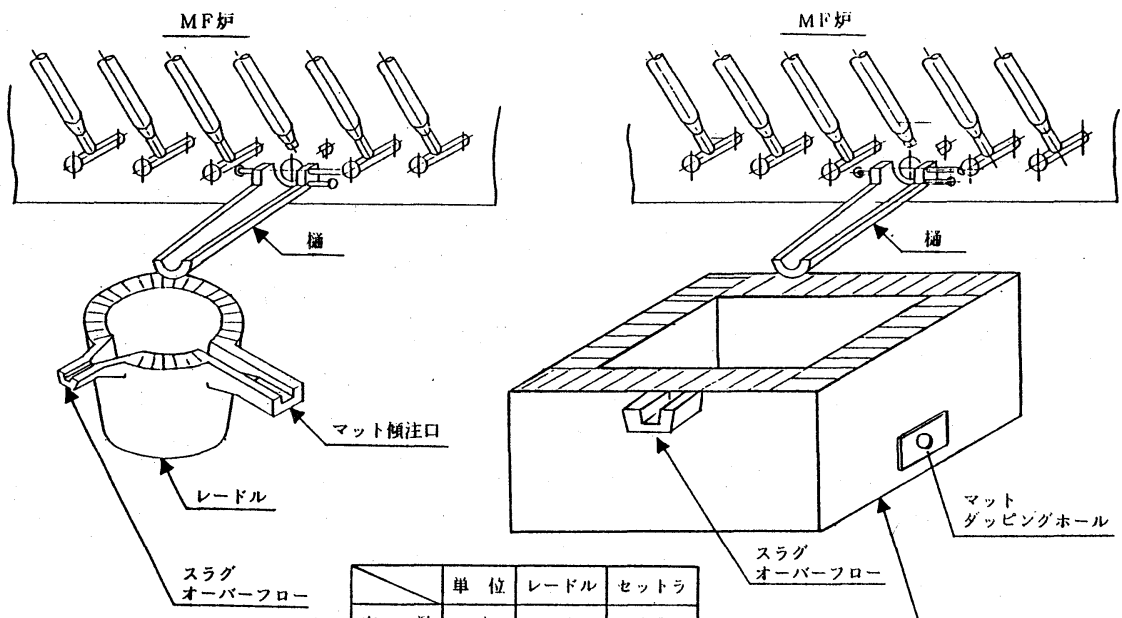

橧

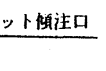

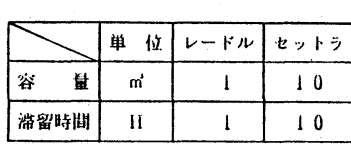

第8図 $M F$ 炉セットラ改造
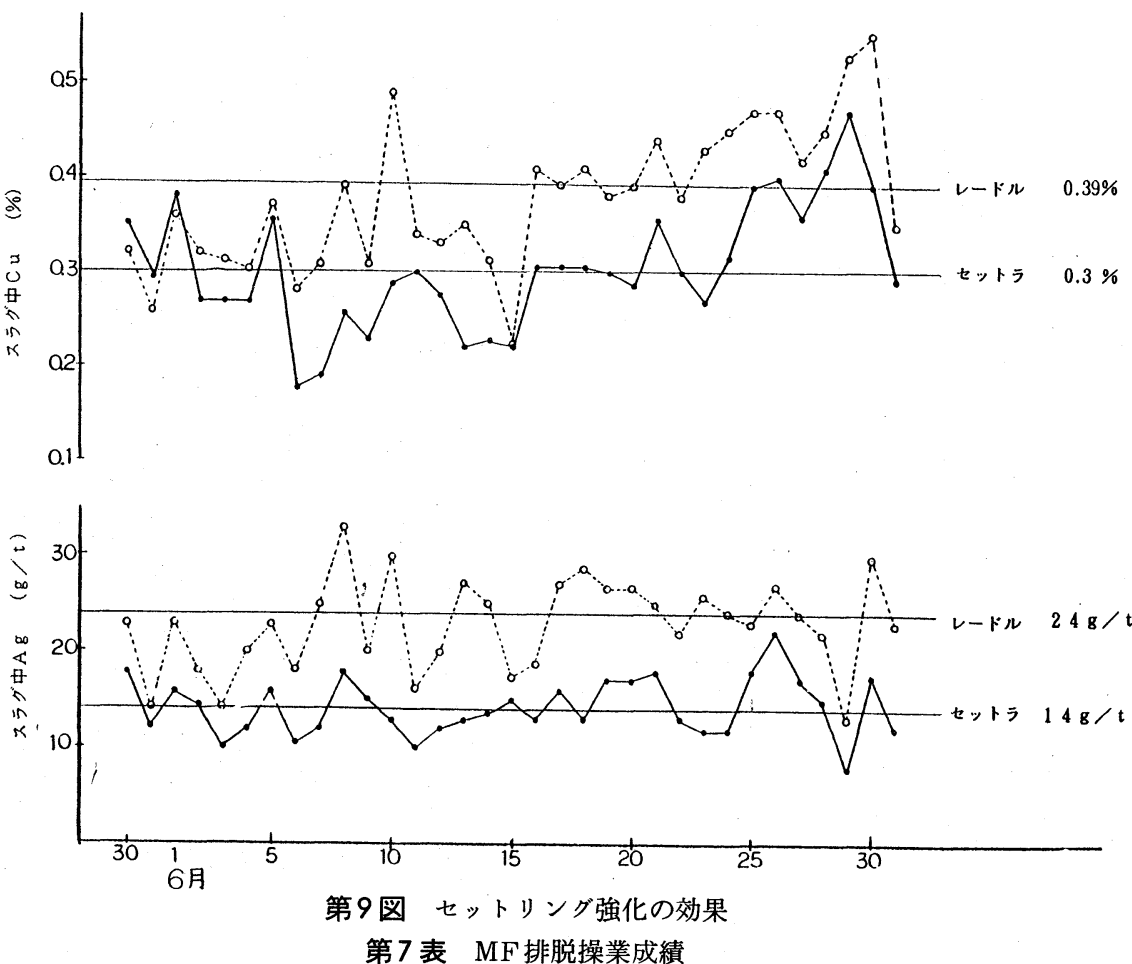

第7表 MF排脱操業成績

\begin{tabular}{|c|c|c|c|c|c|}
\hline 力石 & 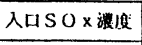 & 出口 S O x 湛设 & 脱 $\mathrm{s}$ 㳯 & 座出石藏 & 政双塔 \\
\hline $\mathrm{Nm} / \mathrm{H}$ & $\mathrm{p} \mathrm{p} \mathrm{m}$ & $\mathrm{ppm}$ & $\%$ & $t / 月$ & n. \\
\hline 120.000 & 300 & 5 & 98 & 200 & $5.200^{\phi} \times 17.0000^{11}$ \\
\hline
\end{tabular}

第 8 表 湿式脱塩素処理鉱種

\begin{tabular}{|c|c|c|c|c|c|}
\hline & 钩 & $\mathrm{C} 1$ & 係外除去C1 Net & 処 理 & 口 \\
\hline & $\mathrm{t} / \mathrm{H} /$ & $\%$ & $t /$ 期 & 盖 前 & 改 \\
\hline 堅㤠バックダスト & 1. 0000 & 7 & 67 & 㹂型工栓梠返し & 湿式脱塭素 - R K 処理 \\
\hline 堅型 OVC, /n 末 & 300 & 2 & 5 & " & $"$ \\
\hline T D 妒 详 & 1.500 & 3 & 40 & " & $\mathrm{R} \mathrm{K}$ 如 理 \\
\hline R K ダスト & 900 & 10 & 87 & RK工程枳返 & 濉式脱的素- R K 処理 \\
\hline Total & 3.700 & 6 & 199 & & \\
\hline
\end{tabular}

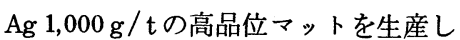
ている。

また，鍰とマットの分離を良くする ため, MF の前床を, 従来の傾転式レ

ードルから, 大型セットラ・マットタ ッピング方式に変更し, 分離効果を高 めた。

セットラの概念図およびセットラの 効果を第 8 図および第 9 図に示す。

$3 \cdot 5 \mathrm{MF}$ 排脱の設置

MF 炉の排ガスに対して, 塩基性硫 酸アルミ法による排脱設備を設置した。 排脱の操業成績を第 7 表に示す。

$3 \cdot 6 \mathrm{RK}$ 鉱の品質確保

製鋼煙灰の供用増により，系内の塩

素負荷が高くなり，RK 鉱の塩素品位 が高くなつた。

この結果, 立型蒸留工程で, 塩化物 発生によるドラフトの低下，レトルト の寿命短縮などの重大なトラブルを生 じた。

このため系内の塩素高含有ダスト類 を湿式法により脱塩素し, 工程に繰返 すことを行なつた。

また， RK 炬の燃焼管理の強化をは かつて, RK 鉱の品質確保を行なつて いる。

塩素高含有ダスト類の脱塩素処理法 を第 8 表に示す。

\subsection{RK排脱の改善}

$\mathrm{RK}$ 炉の排ガスの排脱は，簡易洗浄 塔方式から苛性ソーダによる本格的な 排脱方法へ切替えた。

なお吸収剤として, 副生ソーダ灰等 を利用し, 運転コストを低減させている。 排脱の操業成績を第 9 表に示す。

$3 \cdot 8$ 塩基性炭酸要鉛の製造

RK 炬から発生する RK 煙灰から， 湿式処理により，塩基性炭酸窜鉛およ び鉛涬を製造している。

\section{4. 結言}

今回は, 鈗涬処理工程の改善のみに ついて述べたが, 今後は, 立型蒸留工 程の改善を含めて, $\mathrm{MF}$ - RK-立型蒸 留一連の製鍊方式の立場で，なお一層 の効率化をはかることが急務である。

リサイクル原料は, 今後, 社会の変

第9 表 RK排脱操業成續

\begin{tabular}{|c|c|c|c|}
\hline 力不量 & 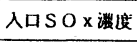 & 山口S O X 㵋度 & 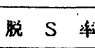 \\
\hline $\mathrm{N} \mathrm{m} / \mathrm{HI}$ & p pm & $\mathrm{pp} \mathrm{m}$ & $\%$ \\
\hline 45,0000 & 1,000 & 5 & 99.5 \\
\hline
\end{tabular}


化につれて多種・多様化してくるであろう。

いかなる原料でも低コストで処理できる体制を作つていくこと
が，われわれに与えられた大きな課題である。

微力ではあるが全力をつくして, その実現に努めていきたい。

\section{（4）カドミウム蒸溜精製工程の改善について}

$\begin{array}{cccc}\text { 住友金属鉱山 (株) 播磨事業所 } & \text { 牧 野 } & \text { 進 } \\ \text { " } & \text { " } & \text { 田 } & \text { 中 信 寛 } \\ & \text { " } & \text { 米 坂 图 俊 }\end{array}$

\section{1. は じめに}

当事業所は, I SP 法（鉛・亜鉛の同時製鍊法）を採用しており， その副産品回収工程としてのカドミウム回収設備は昭和 41 年 5 月 に $10 \mathrm{t} /$ 月の生産能力をもつて操業を開始, その後, 昭和 43 年 10 月に $20 \mathrm{t} /$ 月に設備能力を増強し, 現在に至つている。

本報は, カドミウム回収工程の省エネルギーとコストダウンを 目的として, 昭和56年10月に実施したカドミウム蒸溜炉大型化と その後の操業改善について述べる。

\section{2. カドミウム回収工程の概要}

\section{2 - 1 原料}

当事業所のカドミウム原料は亜鉛精鉱, 2 次原料中に含まれる カドミウムが焼結工程で揮発し煙灰洗浄水に溶出したものと, 亜 鉛精溜塔で揮発, 回収した亜鉛一カドミウム合金に大別される。

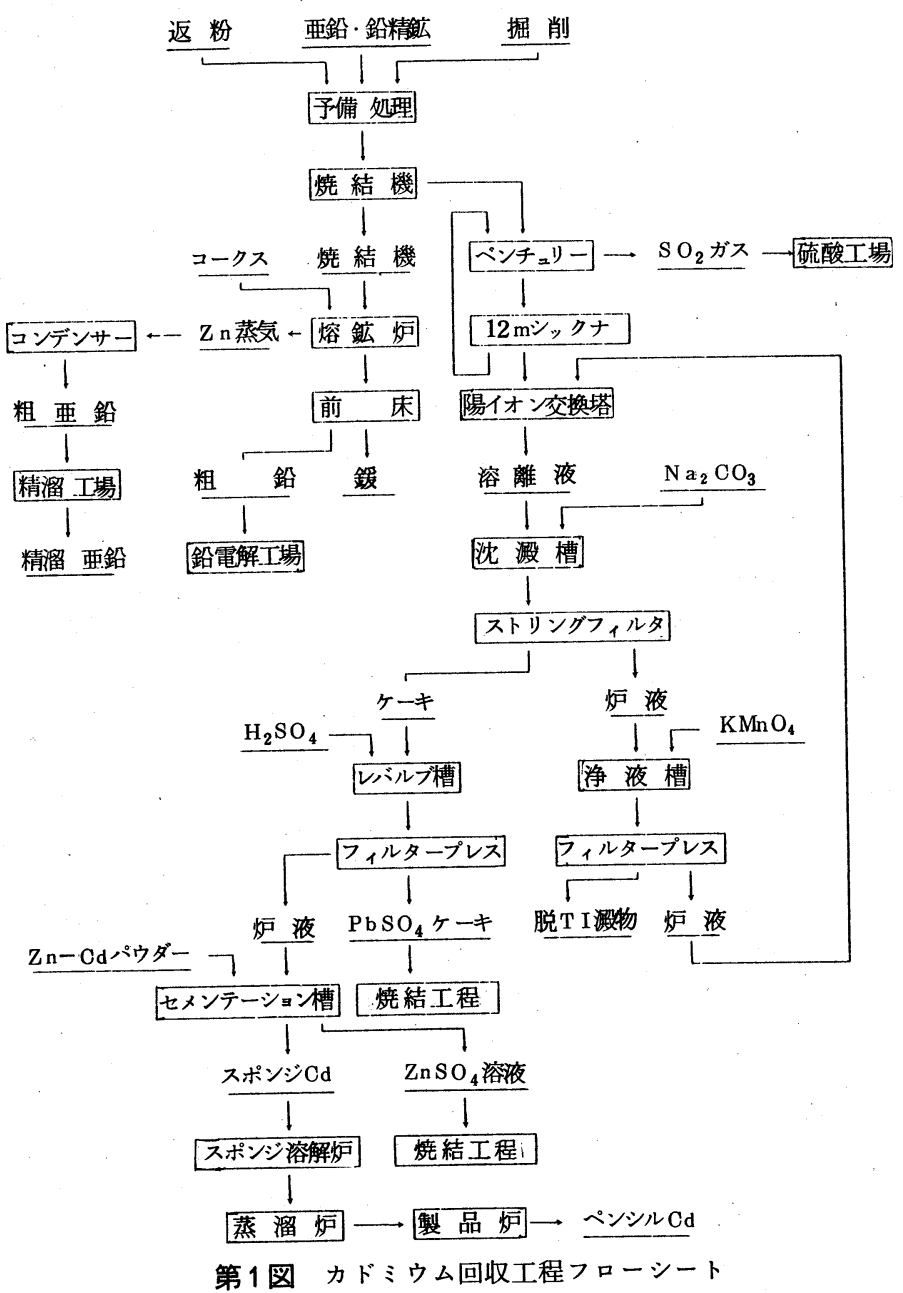

第1表 精製カドミウム分析品位 (単位 \%)

\begin{tabular}{|c|c|c|c|c|c|}
\hline & $\mathrm{Cd}$ & $\mathrm{Pb}$ & $\mathrm{Fe}$ & $C 11$ & $\mathrm{Zn}$ \\
\hline 情製カドミウム & $\geq 99.995$ & 0.0004 & 0.0001 & 0.0001 & 0.0001 \\
\hline I I S 1 拜焻格 & $\geqq 99.99$ & $\leq 0.006$ & $\leq 0.002$ & $\leqq 0.003$ & $\leqq 0.002$ \\
\hline
\end{tabular}

$(\mathrm{t} /$ 年)

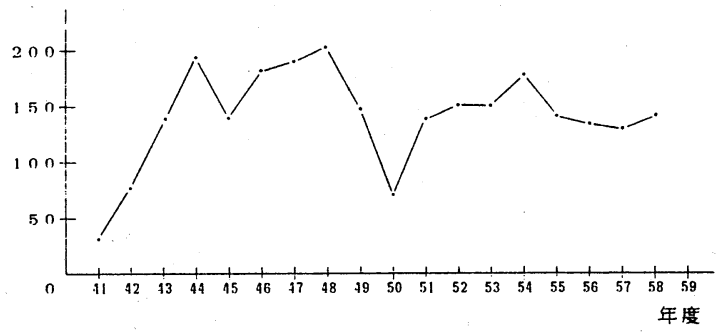

第2図 精製カドミウム生産量推移

\section{$2 \cdot 2$ 工程の概要}

カドミウム回収工程のフローシートを第 1 図に示す。 カドミウムを含む液からイオン交換樹脂で回収, 溶離し, 炭酸塩として沈殿させた後, 硫酸で溶解し, 鉛分をろ過除 去した液を带鉛一カドミウムパウダーでセメンテーション 反応によりスポンジカドミウムとして回収する。

このスポンジカドミウムを溶解炬にて, 苛性ソーダとと もに溶解し, 亜鉛等の不純物を除去した後, 粗カドミウム として鋳造する。

この粗カドミウムを蒸溜炉で揮発, 凝縮させ, これを製 品炉で $1 \mathrm{~kg}$ のペンシル状に鋳込んで精製カドミウムとする。 $2 \cdot 3$ カドミウム蒸溜炉の概要

蒸溜炉は, 溶解工程のフィードボックス, 揮発工程のレ トルトと凝縮工程のコンデンサーからなつている。

単重約 $13 \mathrm{~kg}$ の粗カドミウムインゴットは, フィードボ ックスにて LPGより加熱・溶解され，レトルトに流し込 まれる。

レトルトでは, レンガ張りの炉内面に埋めこまれた抵抗 体の電気ェネルギーにより揮発して蒸気になり,これをレ トルト先端のコンデンサにて補集, 凝縮し, 精製カドミウ ムを得る。

精製カドミウムの代表的分析品位を第 1 表に示すととも に精製カドミウム生産量の推移を第 2 図に示す。

\section{3. カドミウム䓏溜炉大型化 (第 1 次省エネ)}

\section{$3 \cdot 1$ 改善の概要}

操業当初は, カーボランダムのレトルト, コンデンサを 備えた小型蒸溜炉が 3 基あり, このうち $1 \sim 2$ 基が常時運 転され, その間休炬中の炬は, レトルト, コンデンサの整

日本鉱業会誌/101 $1166(' 85-4) 251<11>$ 